University of Wollongong

Research Online

Faculty of Engineering - Papers (Archive)

Faculty of Engineering and Information

Sciences

2002

\title{
Transmission electron microscopy evidence for phase transformation from Bi2Sr2CuO6 to Bi2Sr2Ca2Cu3010
}

W. M. Chen

Nanjing University, China

G. Li

University of Wollongong

S. S. Jiang

Nanjing University, China

H. Y. Ling

University of Wollongong

P. Yao

University of Wollongong, peiyao@uow.edu.au

See next page for additional authors

Follow this and additional works at: https://ro.uow.edu.au/engpapers

Part of the Engineering Commons

https://ro.uow.edu.au/engpapers/142

\section{Recommended Citation}

Chen, W. M.; Li, G.; Jiang, S. S.; Ling, H. Y.; Yao, P.; Qin, M. J.; Liu, Hua-Kun; and Dou, S X.: Transmission electron microscopy evidence for phase transformation from Bi2Sr2CuO6 to Bi2Sr2Ca2Cu3010 2002. https://ro.uow.edu.au/engpapers/142 


\section{Authors}

W. M. Chen, G. Li, S. S. Jiang, H. Y. Ling, P. Yao, M. J. Qin, Hua-Kun Liu, and S X. Dou 


\title{
Transmission electron microscopy evidence for phase transformation from $\mathrm{Bi}_{2} \mathrm{Sr}_{2} \mathrm{CuO}_{6}$ to $\mathrm{Bi}_{2} \mathrm{Sr}_{2} \mathrm{Ca}_{2} \mathrm{Cu}_{3} \mathrm{O}_{10}$
}

\author{
W. M. Chen ${ }^{\text {a) }}$ \\ Department of Physics and National Laboratory of Solid State Microstructures, Nanjing University, \\ Nanjing 210093, People's Republic of China and Institute for Superconducting and Electronic Materials, \\ University of Wollongong, NSW 2522, Australia \\ G. Li \\ Institute for Superconducting and Electronic Materials, University of Wollongong, NSW 2522, Australia \\ S. S. Jiang \\ Department of Physics and National Laboratory of Solid State Microstructures, Nanjing University, \\ Nanjing 210093, People's Republic of China

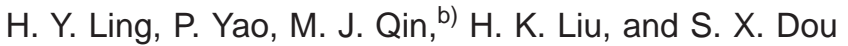 \\ Institute for Superconducting and Electronic Materials, University of Wollongong, NSW 2522, Australia
}

(Received 26 November 2001; accepted for publication 22 May 2002)

\begin{abstract}
The growth mechanism of the Bi-2223 phase was studied using multifilamentary Ag/Bi-2223 tapes manufactured by the powder-in-tube method. X-ray powder diffraction was performed to analyze the developments of $\mathrm{Bi}-2201, \mathrm{Bi}-2212$, and $\mathrm{Bi}-2223$ phases during sintering periods at high temperatures. Transmission electron microscopy (TEM) was used to investigate the growth mechanism of the 2223 phase. TEM images indicated that 2201 and $\mathrm{Ca}_{2} \mathrm{CuO}_{3}$ crystals come together to form platelets of 2223. The structural phase transformation established a structural frame of the 2223 crystal. There were some vacant defects retaining in the established 2223 crystal cells at copper and oxygen sites after the phase transformation, and the $\mathrm{Cu} / \mathrm{O}$ compound at high temperatures would diffuse into 2223 cells and occupy the corresponding vacancies to complete the 2223 crystal structure. The present work provides an evidence for growing the 2223 phase from the 2201 phase and $\mathrm{Ca}_{2} \mathrm{CuO}_{3}$ in the samples studied. (C) 2002 American Institute of Physics.
\end{abstract}

[DOI: $10.1063 / 1.1492856$ ]

There are three compounds in the Bi system: Bi-2201, Bi-2212, and Bi-2223, in which 2223 is of the greatest interest due to its high $T_{c}$ and the potential for commercial applications. The understanding of the formation mechanism was important for the efficient preparation of Bi-2223 superconductors with high quality. It has been found that the 2223 phase may grow from the $\mathrm{Bi}-2212$ phase by solid state reaction at high temperatures. ${ }^{1-13}$ The primary mechanism of growing the $\mathrm{Bi}-2223$ phase was thought to be the $\mathrm{Ca} / \mathrm{CuO}_{2}$ layers intercalating into Bi-2212 crystals at high temperatures. $^{2-4} \mathrm{~A}$ corresponding layer rigidity model of growing the 2223 phase was suggested. ${ }^{5,6}$ Some different mechanisms of growing the Bi-2223 phase were also suggested, such as the growth of the 2223 phase directly from liquid amorphous ${ }^{4}$ or in the form of $2212 \rightarrow 2201 \rightarrow 2223$. $^{14}$ Up to now, people only widely accepted that the 2223 phase might grow from the 2212 phase. Whereas, it was believed that the processes of growing 2223 were not thoroughly revealed, because the phase diagrams describing the growth of polycrystalline 2223 were complicated. ${ }^{13-17}$

It was believed that if some of the 2223 phase did not grow from the 2212 phase, such that the 2223 phase might retain some trace of its origins. The trace would leave a

\footnotetext{
a) Author to whom correspondence should be addressed; present address: Institute for Superconducting \& Electronic Materials, University of Wollongong, NSW 2522, Australia.

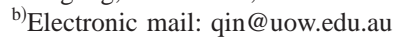

record giving some information on the mechanism, which could be observed in transmission electron microscopy (TEM) image fields.

The starting material was a commercial oxide powder, with a stoichiometry of $\mathrm{Bi}(\mathrm{Pb}): \mathrm{Sr}: \mathrm{Ca}: \mathrm{Cu}=2: 2: 2: 3$. The starting powder was thoroughly ground and became amorphous materials. ${ }^{18}$ The Bi-2223 compound was prepared in the silver sheathed tapes, because the 2223 phase in the multifilament tapes has a better preferential orientation than in bulk, ${ }^{19}$ and a good orientation of grains has advantages for TEM observation.

Multifilamentary Ag/2223 tapes were manufactured by the powder-in-tube method. ${ }^{20-22}$ The sintering temperature was $840^{\circ} \mathrm{C}$, for $2,10,20,30$, and $50 \mathrm{~h}$.

Figure 1 shows patterns of $\mathrm{x}$-ray diffraction for tapes with sintering periods of $2,10,20,30$, and $50 \mathrm{~h}$, respectively. Figure 1 shows records of the 2201, 2212, and 2223 phase forming, developing, and/or transforming, during the sintering period at $840{ }^{\circ} \mathrm{C}$. It is found that the development of the 2212 phase is faster than that of the 2201 and 2223 phases. 2212 is the main phase during the first $10 \mathrm{~h}$ sintering and then transforms rapidly as the sintering period increases, so that at the end of $50 \mathrm{~h}$ sintering it only constitutes a trace amount in the tape. The development of the 2201 phase is similar to, but more slowly than that of 2212. It reaches its maximum amount at the end of $30 \mathrm{~h}$ sintering and then be- 


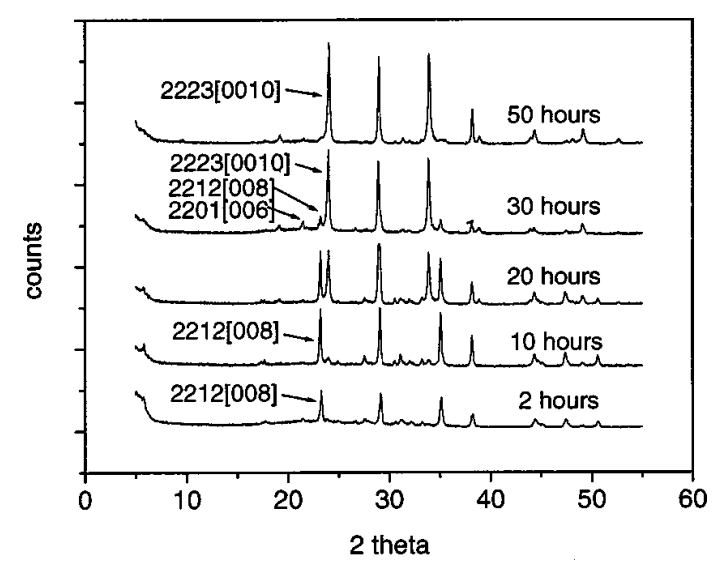

FIG. 1. The 2212 phase develops rapidly before $20 \mathrm{~h}$ sintering, then is quickly eliminated, almost disappearing by the end of $50 \mathrm{~h}$ sintering. Similarly to 2212, 2201 develops and reaches its maximum amount at the end of $30 \mathrm{~h}$ sintering. It is then eliminated, and only a trace amount remains after $50 \mathrm{~h}$ sintering. The 2223 phase grows steadily throughout sintering and has almost replaced the 2201 and 2212 phases at the end of $50 \mathrm{~h}$ sintering.

gins to disappear, so that it is less than $5 \%$ in amount after 50 $\mathrm{h}$ sintering. The 2223 phase growth proceeds throughout the sintering period. It appears when $10 \mathrm{~h}$ sintering and both 2223 and 2212 are the main phases after $20 \mathrm{~h}$ sintering. 2223 by the end of $30 \mathrm{~h}$ sintering becomes the main phase and is completed at the end of $50 \mathrm{~h}$ sintering.

Since 2201, 2212, and 2223 phases have well preferential orientation on $c$ axis, the strength of the characterized diffraction peaks [006], [008], and [0010] may quantitatively describe the development of 2201, 2212, and 2223 phase, respectively. The relative changes of peaks [006], [008], and [0010] during the sintering period are listed in Table I. Percent strengths of the corresponding peaks are relative to that of the maximum peak in each pattern and the maximum is taken to be $100 \%$. X-ray analysis shows that dissolving the 2201 and/or 2212 phases both finally contribute to the 2223 phase development. It was already well known that the 2201 phase may change into the 2212 phase. ${ }^{23}$ It was suggested that the tape resulting from $50 \mathrm{~h}$ sintering might retain some evidence that recorded how the 2212 or 2201 phase was dissolved and transformed into the 2223 phase. So, we carefully examined that tape by TEM.

When searching the TEM field of view, the 2201, 2212, and 2223 phases as well as some impurity phases, such as $\mathrm{Ca}_{2} \mathrm{CuO}_{3}$ and $\mathrm{CuO}$, were often observed. A special morphology of platelets consisted of the 2223 and 2201 phases and a $\mathrm{Ca}_{2} \mathrm{CuO}_{3}$ compound was found and shown in Fig. 2. It is

TABLE I. Development of phases depends on the sintering period. For tapes with good preferential orientation, the composition of each phase in the tape may be characterized by the corresponding characteristic peak. Values of corresponding characteristic peaks are relative to that of the maximum peak in each pattern and the maximum is determined to be $100 \%$.

\begin{tabular}{lccc}
\hline \hline Phases & 2201 & 2212 & 2223 \\
peaks & {$[006]$} & {$[008]$} & $(\%)$ \\
$(\mathrm{h})$ & $(\%)$ & 93 & $(\%)$ \\
\hline 10 & 2 & 86 & 10 \\
20 & 3 & 11 & 89 \\
30 & 5 & 3 & 100 \\
50 & 3 & 100
\end{tabular}

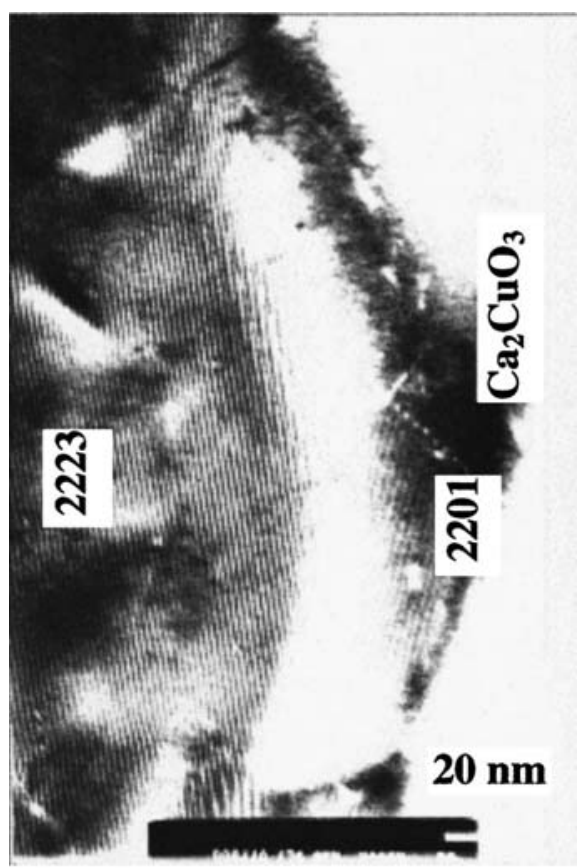

FIG. 2. There are three phases in the grain. The main portion of the grain is the 2223 phase, the two second phases on the left of the image have been determined to be 2201 and $\mathrm{Ca}_{2} \mathrm{CuO}_{3}$. The 2223 grain is growing from left to right. There are second phases remaining on the left. There are transition regions visible between the 2223 phase and the two second phases.

noted that there is no 2212 phase around the grown 2223 platelets, but 2201 and $\mathrm{Ca}_{2} \mathrm{CuO}_{3}$ phases are found close to the 2223. Physical intuition tells us that the 2223 phase may come from the combination of the 2201 phase with $\mathrm{Ca}_{2} \mathrm{CuO}_{3}$.

TEM further focused on the combined zone of the three phases and a more detailed image was taken and shown in Fig. 3. 2223, $\mathrm{Ca}_{2} \mathrm{CuO}_{3}$, and 2201 platelets are found in both Figs. 2 and 3. In Figs. 2 and 3, the bright dot lines sloping from the upper left to the lower right are the crystal boundary between $\mathrm{Ca}_{2} \mathrm{CuO}_{3}$ and 2201. We find a special transition region with high brightness at the upper left in Fig. 3, in which $\mathrm{Ca}_{2} \mathrm{CuO}_{3}$ and 2201 platelets at the region of their boundary are coming together and become a new crystal lattice in the form of 2223 platelets. The transition region in the form of triangularity extends from the upper right to the lower middle part of Fig. 3. Platelets in the transition region are developing into matured 2223 crystals and the 2223 crystal in Fig. 3 is growing from left to right. Therefore, Fig. 3 shows the evidence that the 2223 phase can develop from the 2201 phase combining with $\mathrm{Ca}_{2} \mathrm{CuO}_{3}$ compound.

Similarly, the process of insertion $\mathrm{Ca}-\mathrm{Cu}-\mathrm{O}$ Bi-layers into the existing 2212 to form 2223 can be accomplished by the diffusion through the edge at the growth fronts of the layers. ${ }^{2,24,25}$ And an intercalation mechanism was also invoked for the phase conversion of Bi-2201 to Bi-2212 from an amorphous precursor. ${ }^{26}$ It is noted the similarity existing among the conversions of 2201 and 2212 into 2223 and that of Bi-2201 to Bi-2212. For the highly anisotropic crystals, such as Bi-2212 and Bi-2223 crystals, it appears reasonable that platelet insertion mechanism is the mechanism for the phase conversion.

The growth 2223 phase through the combination of the

Downloaded 15 Aug 2006 to 130.130.37.6. Redistribution subject to AIP license or copyright, see http://apl.aip.org/apl/copyright.jsp 


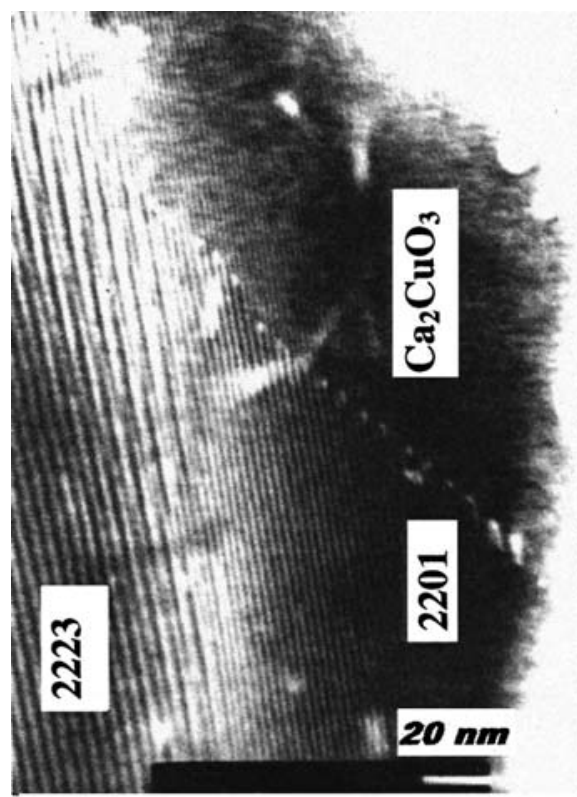

FIG. 3. This is an image of a transition region with high brightness, starting from the upper right and extending down towards the lower middle of Fig. 2. In the upper right of the image, $\mathrm{Ca}_{2} \mathrm{CuO}_{3}$ and 2201 platelets are joining together, with the pieces of the $\mathrm{Ca}_{2} \mathrm{CuO}_{3}$ platelet diffusing into broken 2201 platelets. These eventually react completely to form the 2223 platelets as can be seen in the bright area at the lower middle of the image.

2201 phase with $\mathrm{Ca}_{2} \mathrm{CuO}_{3}$ compound constitutes an entirely different mechanism. It is noted that the lattice constants for the $c$ axis of the 2201 phase and the $\mathrm{Ca}_{2} \mathrm{CuO}_{3}$ crystal are, respectively, $2.51^{7}$ and $1.22 \mathrm{~nm},{ }^{27}$ and the sum of the two is $3.73 \mathrm{~nm}$, the same dimension as the $c$-axis lattice parameter of the 2223 crystal cell. ${ }^{7}$ Obviously, the growth mechanism of the 2223 phase is a structural phase transformation, and, in this case, it does not cause a change of dimensions and is known as the second type of phase transformation. The second type of phase transformation does not require extra mechanical energy to drive the transformation. It means that the phase transformation may be completed without any pressure. Thus, the transformation can arise under the circumstances of the sintering processes that take place during the manufacture of Bi-2223 tapes. Furthermore, this phase transformation is completed through the route of physical diffusion at high temperatures.

In view of the chemical reactions, the reaction should be in the form of

$$
\mathrm{Bi}_{2} \mathrm{Sr}_{2} \mathrm{CuO}_{6}+\mathrm{Ca}_{2} \mathrm{CuO}_{3}+\mathrm{CuO}=\mathrm{Bi}_{2} \mathrm{Sr}_{2} \mathrm{Ca}_{2} \mathrm{Cu}_{3} \mathrm{O}_{10} \text {. }
$$

Whereas, there is no evidence of $\mathrm{CuO}$ to be found in the observed microregion. It is noted that this problem we face involves a physical structure transition, not a pure chemical reaction. It means that this transition establishes a crystal structure with the space group $14 / \mathrm{mmm}$ of the 2223 crystal, and its ideal stoichiometry shall be $\mathrm{Bi}_{2} \mathrm{Sr}_{2} \mathrm{Ca}_{2} \mathrm{Cu}_{3} \mathrm{O}_{10}$. Since there is no $\mathrm{CuO}$ to be found in the reaction region, the frame of the crystal structure has been established after the transformation occurred. This implies that there should be two vacancies; one in a copper site and the other in an oxygen site, existing in each 2223 crystal cell immediately after the transformation is completed. The established crystal frame has vacant defects with it and, therefore, it is not perfect. If

Downloaded 15 Aug 2006 to 130.130.37.6. Redistribution subject to AIP license or copyright, see http://apl.aip.org/apl/copyright.jsp we discuss this problem from the view of the chemical reaction as well, Eq. (1) should be changed into the form of

$$
\mathrm{Bi}_{2} \mathrm{Sr}_{2} \mathrm{CuO}_{6}+\mathrm{Ca}_{2} \mathrm{CuO}_{3}=\mathrm{Bi}_{2} \mathrm{Sr}_{2} \mathrm{Ca}_{2} \mathrm{Cu}_{3} \mathrm{O}_{10}-\mathrm{CuO} \text {. }
$$

After $30 \mathrm{~h}$ sintering, the 2223 crystal with the vacant defects of copper and oxygen sites becomes the main phase, and the required $\mathrm{CuO}$ exists in the tape, because of the starting material for producing the 2223 compound having a stoichiometry of the ratio of $\mathrm{Bi}(\mathrm{Pb}): \mathrm{Sr}: \mathrm{Ca}: \mathrm{Cu}=2: 2: 2: 3$. It is noted that the dimensions of the $\mathrm{CuO}$ crystal cell are only 0.34-0.52 nm, ${ }^{7}$ much less than that of $\mathrm{Bi}_{2} \mathrm{Sr}_{2} \mathrm{CuO}_{6}$ or $\mathrm{Ca}_{2} \mathrm{CuO}_{3}$. At high temperatures, smaller cells diffuse easily. Therefore, it is believed that the required copper and oxygen atoms will diffuse into 2223 cells and occupy the corresponding vacancies to complete the 2223 crystal structure after long period sintering at high temperatures.

In summary, TEM images have provided evidence for the phase transformation from 2201 and $\mathrm{Ca}_{2} \mathrm{CuO}_{3}$ crystals to Bi-2223, through the diffusion of $\mathrm{Ca}_{2} \mathrm{CuO}_{3}$ platelet pieces into 2201 platelets at high temperatures in the samples studied. Each 2223-crystal cell established after the phase transformation has two vacant defects, one in a copper site and the other in an oxygen site. At high temperatures, the required copper and oxygen atoms will diffuse into 2223 cells and occupy the corresponding vacancies to complete the 2223 crystal structure.

${ }^{1}$ M. Taracon, Y. LePage, L. H. Green, G. B. Baley, Bardoux P. Huang, D. M. Hall, W. Mickinnon, and W. R. Grigin, Phys. Rev. B 38, 2504 (1988)

${ }^{2}$ Z. X. Cai, Y. Zhu, and D. O. Welch, Phys. Rev. B 52, 13035 (1995).

${ }^{3}$ Y. L. Wang, W. M. Bian, Y. Zhu, Z. X. Cai, D. O. Welch, R. L. Sabatini, and M. Suenaga, Appl. Phys. Lett. 69, 580 (1996).

${ }^{4}$ Z. X. Cai and Y. Zhu, Microstructures and Structural Defects in HighTemperature Superconductors (World Scientific, Singapore, 1998); p. 237.

${ }^{5}$ M. F. Thorpe, W. Jin, and S. D. Mahanti, Phys. Rev. B 40, 10294 (1989).

${ }^{6}$ Y. Cai, J. S. Chung, M. F. Thorpe, and S. D. Mahanti, Phys. Rev. B 42, 8827 (1990).

${ }^{7}$ E. Giannini, E. Bellingeri, R. Passerini, and R. Flukiger, Physica C 315, 185 (1999).

${ }^{8}$ W. Zhu, C. K. Kuo, and P. S. Nicholson, J. Mater. Res. 14, 4143 (1999).

${ }^{9}$ J. C. Grivel and R. Flukiger, Supercond. Sci. Technol. 11, 288 (1998).

${ }^{10}$ N. Kijima, H. Endo, J. Tsuchiga, A. Suniyama, M. Mizuno, and Y. Oguri, Jpn. J. Appl. Phys., Part 2 27, L1852 (1988).

${ }^{11}$ J. W. Ko, J. Yoo, H. D. Kim, and H. Chung, Physica C 341, 2023 (2000).

${ }^{12}$ A. Tampieri and G. Celotti, Supercond. Sci. Technol. 13, 1113 (2000).

${ }^{13}$ P. Majewski, Supercond. Sci. Technol. 10, 453 (1997).

${ }^{14}$ Y. L. Chen and R. J. Stevens, J. Am. Ceram. Soc. 75, 1150 (1992).

${ }^{15}$ W. Wongng, L. P. Cook, F. Jiang, W. Greenwood, U. Balachandran, and M. Lanagan, J. Mater. Res. 12, 2855 (1997).

${ }^{16}$ S. Bernik, M. Hrovat, and D. Kolar, Supercond. Sci. Technol. 7, 920 (1994).

${ }^{17}$ Y. T. Huang, D. S. Shy, and L. J. Chen, Physica C 294, 140 (1998).

${ }^{18}$ W. M. Chen, Phys. Rev. B 57, 7503 (1998).

${ }^{19}$ W. M. Chen, F. Wang, F. Lin, S. S. Jiang, Y. C. Guo, H. K. Liu, and S. X. Dou, J. Supercond. 13, 441 (2000).

${ }^{20}$ W. M. Chen, Y. C. Guo, X. K. Fu, H. K. Liu, S. X. Dou, and M. Apperley, IEEE Trans. Appl. Supercond. 11, 3752 (2001).

${ }^{21}$ W. M. Chen, Y. C. Guo, G. McCaughey, M. Apperley, H. K. Liu, and S. X. Dou, Physica C 354, 349 (2001).

${ }^{22}$ W. Assmus and W. Schmidbauer, Supercond. Sci. Technol. 6, 555 (1993).

${ }^{23}$ B. Heeb, L. J. Gauckler, H. Heinrich, and G. Kostorz, J. Mater. Res. 8, 2170 (1993).

${ }^{24}$ Z. X. Cai and Y. Zhu, Mater. Sci. Eng., A 238, 210 (1997).

${ }^{25}$ W. Bian, Y. Zhu, Y. L. Wang, and M. Suenaga, Physica C 248, 119 (1995).

${ }^{26}$ M. J. Kramer, R. W. McCallum, L. Margulies, S. R. Arrasmith, and T. G. Holesinger, J. Electron. Mater. 22, 1269 (1993).

${ }^{27}$ C. Teske and Z. Muller-Buschbaum, Z. Anorg. Allg. Chem. 379, 234 (1970). 